\title{
Effects of Bioconjugation on the Structures and Electronic Spectra of CdSe: Density Functional Theory Study of CdSe-Adenine Complexes
}

\author{
Ho-Sung Kim, Sung-Woo Jang, Sang-Yoon Chung, and Sungyul Lee* \\ Department of Applied Chemistry, Kyung Hee University, 1 Seocheon-dong, Giheung-gu, Yongin-si, \\ Gyeonggi-do 446-701, Republic of Korea
}

\section{Yonghoon Lee Le $^{\dagger}$}

Advanced Photonics Research Institute, Gwangju Institute of Science and Technology, Gwangju 500-712, Republic of Korea

\begin{abstract}
Bongsoo Kim*
Department of Chemistry, Korea Advanced Institute of Science and Technology, Daejon 305-701, Republic of Korea
\end{abstract}

\author{
Christopher Liu and Daniel Neuhauser* \\ Department of Chemistry and Biochemistry, University of California, Los Angeles, California 90095
}

Received: August 10, 2009; Revised Manuscript Received: November 3, 2009

\begin{abstract}
We present density functional theory (DFT) and time-dependent DFT (TD-DFT) study of the structures and electronic spectra of small CdSe nanocluster-adenine complexes $\mathrm{Cd}_{n} \mathrm{Se}_{n}-$ adenine $(n=3,6,10,13)$. We examine the changes in the geometries and excitation spectra of the nanoclusters induced by DNA basebinding. By comparing the results calculated for the bare $\left(\mathrm{Cd}_{n} \mathrm{Se}_{n}\right)$, hydrogen-passivated $\left(\mathrm{Cd}_{n} \mathrm{Se}_{n} \mathrm{H}_{2 n}\right)$, as well as the corresponding adenine (Ade)-bound clusters $\left(\mathrm{Cd}_{n} \mathrm{Se}_{n}-\mathrm{Ade}, \mathrm{Cd}_{n} \mathrm{Se}_{n} \mathrm{H}_{2 n}-\mathrm{Ade}, \mathrm{Cd}_{n} \mathrm{Se}_{n} \mathrm{H}_{2 n-2}-\mathrm{Ade}\right.$ ), we find that binding with Ade slightly blue-shifts (up to $0.18 \mathrm{eV}$ ) the electronic excitations of bare nanoclusters but strongly red-shifts $(<1.2 \mathrm{eV})$ those of hydrogen-passivated nanoclusters. Natural bond orbital analysis shows that the LUMO of $\mathrm{Cd}_{n} \mathrm{Se}_{n} \mathrm{H}_{2 n}$-Ade is a $\pi^{*}$ orbital located on the purine ring.
\end{abstract}

\section{Introduction}

Functionalizing the inorganic surface and nanoclusters is important because it may offer useful routes to design new materials with diverse physicochemical properties. Bottom-up assembly of inorganic-bio/organic interface confers bioactivity to inorganic nanoclusters, producing materials of desirable electronic, optical and chemical properties with wide applications in materials science, chemistry, biology, and medicine. ${ }^{1-5}$ One may fine-tune the binding selectivity of inorganic nanoclusters by combining with biomolecules such as polypeptides or DNA. ${ }^{6-25}$ The physicochemical properties of inorganic nanocluster-biomolecule complexes have allowed their wide applications as fluorescent probes in biological imaging, ${ }^{12-19}$ tunable light absorbers and emitters in nanoscale electronics, ${ }^{20}$ quantum dot lasers, ${ }^{21}$ and biosensing.., 22

CdSe particles and clusters ${ }^{26-40}$ have received a lot of attention because their electronic and optical properties may be varied by controlling characteristics such as the size, ${ }^{41-44}$ shape, ${ }^{43,45}$ and composition. ${ }^{46}$ It is well-known that the absorption band gap in the CdSe cluster blue shifts with reduced size, ${ }^{33}$ making them good quantum dots (QD's) photoemitting over a wide range of wavelengths. An increasing number of studies

* Authors to whom correspondence should be addressed. E-mail addresses: S.L., sylee@khu.ac.kr; B.K., bongsoo@kaist.ac.kr; D.N., dxn@chem.ucla.edu.

Current Address: Department of Chemistry, Mokpo National University, Muan-gun, Jeonnam 534-729, Korea. have also attempted to understand the structures, electronic and optical properties of CdSe clusters in the context of ligand coordination, ${ }^{26-31}$ bioconjugation, ${ }^{6-25}$ and composition stoichiometry. ${ }^{47,48}$ Ishikawa and co-workers ${ }^{41}$ recently determined the geometry of $(\mathrm{CdSe})_{n}$ clusters $(n \leq 13)^{28-30}$ as the precursors nucleated in the solution phase synthesis of the large CdSe QD's by correlating their absorption, PL, and XRD spectra with DFT calculations. Peng and Peng ${ }^{32}$ also studied the temporal shape evolution of CdSe quantum confined nanorods (quantum rods) in nonaqueous solvents with organometallic precursors.

In the present work, we study CdSe cluster-adenine (Ade) complex as a prototypical model for functionalized semiconductor. Our calculated results provide a bridge between the atomistic details of bioconjugation and the corresponding optical properties. We specifically obtain and compare results for the geometry, chemical bonding and the electronic spectra of $\mathrm{Cd}_{n} \mathrm{Se}_{n}$ and $\mathrm{Cd}_{n} \mathrm{Se}_{n} \mathrm{H}_{2 n}(n=3,6,10,13)$ clusters with their Ade complexes. Since the $\mathrm{Cd}_{13} \mathrm{Se}_{13}$ cluster seems to be the smallest cluster exhibiting the structural features of the bulk $\mathrm{CdSe}^{41}$ and is also amenable to the DFT and TDDFT methods employed in this work, we choose it to examine the trends in the structures and the electronic properties that may extrapolate to larger $\mathrm{CdSe}$ system as a function of bioconjugation. The TD-DFT results show that Ade-binding blue-shifts the electronic excitations of bare $\mathrm{Cd}_{n} \mathrm{Se}_{n}$ nanoclusters but red-shifts those of the corresponding hydrogen-passivated nanoclusters $\mathrm{Cd}_{n} \mathrm{Se}_{n} \mathrm{H}_{2 n}$. 


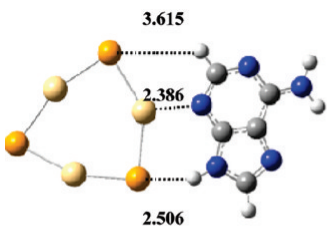

(3-a-1)

$$
\mathbf{E}=\mathbf{0}
$$

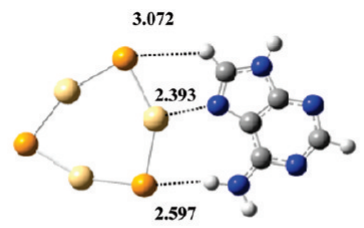

$(3-a-2)$
$\mathrm{E}=\mathbf{2 . 7}$

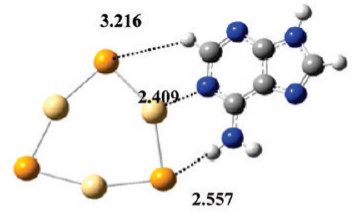

(3-a-3)

Figure 1. Structures of $\mathrm{Cd}_{3} \mathrm{Se}_{3}-\mathrm{Ade}$ complexes (relative energy in $\mathrm{kcal} / \mathrm{mol}$ ).

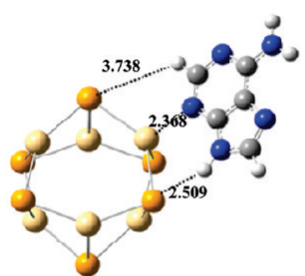

(6-a-1)

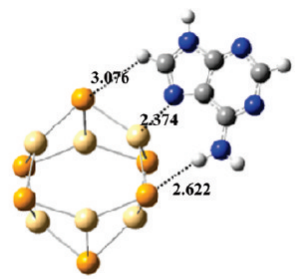

$(6-\mathrm{a}-2) \quad \mathrm{E}=\mathbf{2 . 8}$

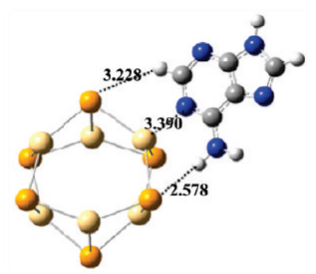

(6-a-3)

$\mathbf{E}=\mathbf{2 . 9}$

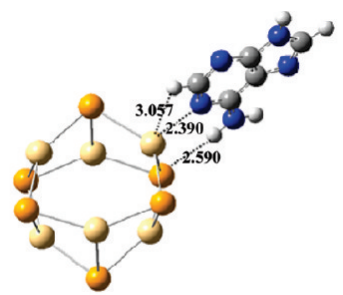

(6-a-4)

$\mathbf{E}=\mathbf{3 . 3}$

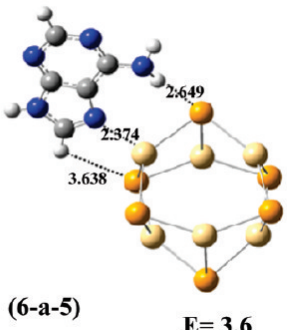

Figure 2. Structures of $\mathrm{Cd}_{6} \mathrm{Se}_{6}-$ Ade complexes (relative energy in $\mathrm{kcal} / \mathrm{mol}$ ).

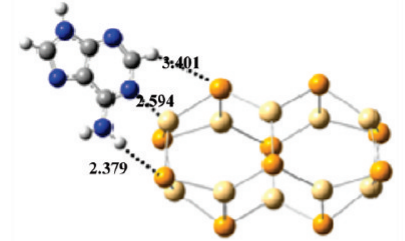

(10-a-1) $\mathbf{E}=\mathbf{0}$

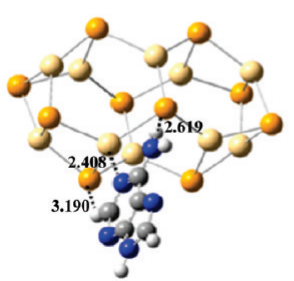

(10-a-4)

$\mathbf{E}=\mathbf{2 . 7}$

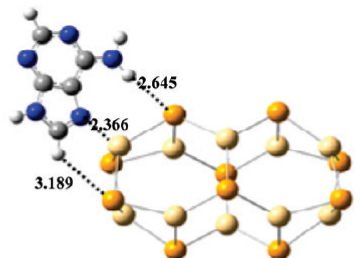

(10-a-2)

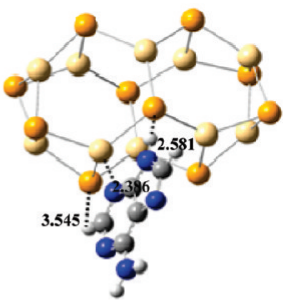

(10-a-3) $\mathbf{E}=\mathbf{0 . 4}$

Figure 3. Structures of $\mathrm{Cd}_{10} \mathrm{Se}_{10}$ - Ade complexes (relative energy in $\mathrm{kcal} / \mathrm{mol}$ ).

\section{Computational Methods}

We employ the DFT and TD-DFT (Time-dependent DFT) methods as implemented in Gaussian 03. ${ }^{49}$ Becke's threeparameter hybrid method ${ }^{50}$ and the correlation functional by Lee, Yang, and Parr ${ }^{51}$ (B3LYP) are used with the 6-311++G** and the Lanl2dz basis set. Stationary structures are obtained by verifying that all the harmonic frequencies are real. Default options are employed for all optimizations. No symmetry constraints are imposed during the optimizations. Natural bond orbital (NBO) analysis was carried out with NBO 3.1 packaged in Gaussian 03.

\section{Results}

III-1. Structures of Unpassivated Clusters: $\mathrm{Cd}_{n} \mathrm{Se}_{n}-$ Ade $(n=3,6,10,13)$. Figures $1-4$ depict the structures and relative energies of the $\mathrm{Cd}_{n} \mathrm{Se}_{n}-$ Ade $(n=3,6,10,13)$ complexes. We find that $\mathrm{Cd}_{n} \mathrm{Se}_{n}(n=3,6,10,13)$ forms the most stable complex with the $9(\mathrm{H})$-Ade, which is the lowest energy conformer of adenine. ${ }^{54}$ In the lowest energy conformer (3-a-1) of $\mathrm{Cd}_{3} \mathrm{Se}_{3}-$ Ade complex, $\mathrm{N} 3$ binds to a $\mathrm{Cd}$ atom and $9(\mathrm{H})$ interacts with $\mathrm{Se}$, in a planar geometry. The energies of the two complexes (3-a-2) and (3-a-3) are similar, 2.7-2.8 kcal/mol above (3-a-1). The amino group interacts with a Se atom in the two complexes, but N7 and $\mathrm{N} 1$ binds to $\mathrm{Cd}$ in (3-a-2) and (3-a-3), respectively. In the lowest energy $\mathrm{Cd}_{6} \mathrm{Se}_{6}-$ Ade complex given in Figure 2, N3 and $9(\mathrm{H})$ bind to neighboring $\mathrm{Cd}$ and Se, respectively. Other conformers are of somewhat higher energy $(>2.8 \mathrm{kcal} / \mathrm{mol})$. We find three low energy conformers of the $\mathrm{Cd}_{10} \mathrm{Se}_{10}-$ Ade complex (Figure 3) whose energies are quite similar, lying within $1 \mathrm{kcal} / \mathrm{mol}$. N1, N7, and N3 bind to Cd in (10-a-1), (10-a-2), and (10-a-3), respectively. In most $\mathrm{Cd}_{n} \mathrm{Se}_{n}-\mathrm{Ade}$ complexes studied, the adenine moiety lies more or less in $\mathrm{Cd}_{n} \mathrm{Se}_{n}$ plane, but adenine and $\mathrm{CdSe}$ are approximately in perpendicular position in the lowest energy $\mathrm{Cd}_{n} \mathrm{Se}_{n}-$ Ade complex (13-a-1) given in Figure 4. 


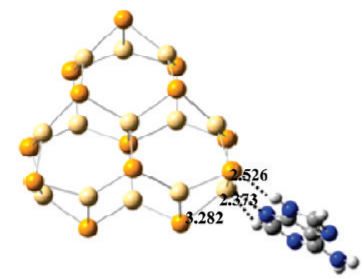

(13-a-1)

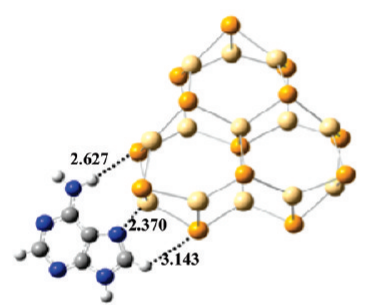

(13-a-4)
$E=2.5$

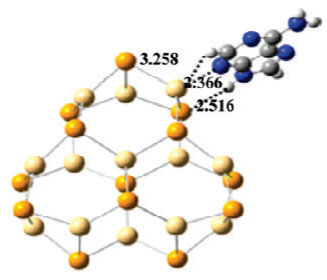

(13-a-2) $\mathbf{E}=\mathbf{1 . 2}$

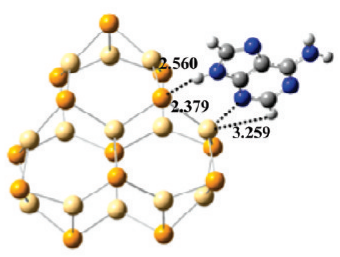

(13-a-3)

$\mathbf{E}=\mathbf{1 . 2}$
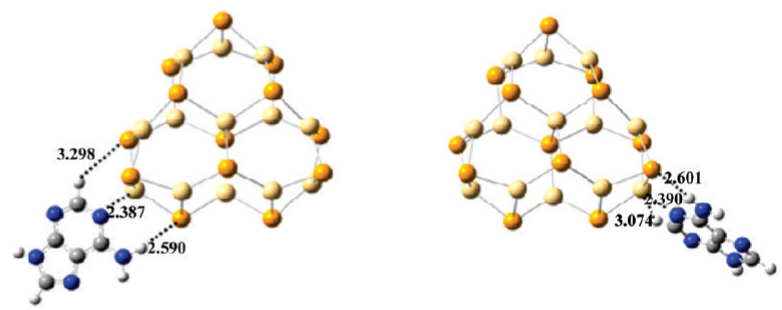

(13-a-5)

$\mathbf{E}=\mathbf{2 . 5}$

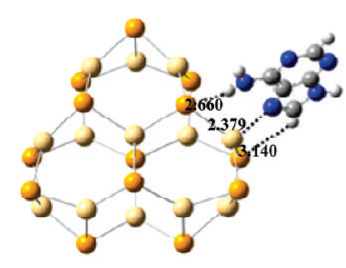

(13-a-7) $\mathbf{E}=3.5$

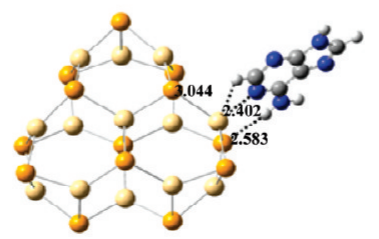

(13-a-8)

$\mathrm{E}=\mathbf{3 . 6}$

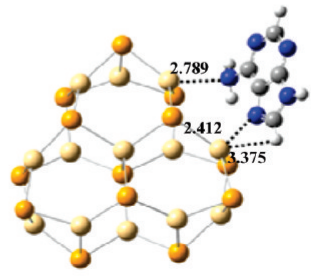

(13-a-9)

$\mathbf{E}=\mathbf{3 . 7}$

Figure 4. Structures of $\mathrm{Cd}_{13} \mathrm{Se}_{13}$-Ade complexes (relative energy in $\mathrm{kcal} / \mathrm{mol}$ ).

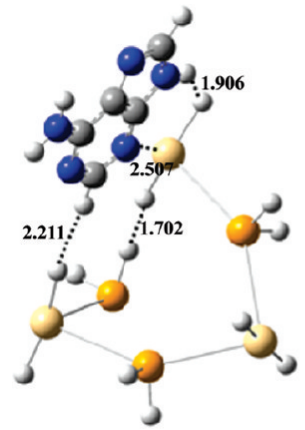

(3-H-a-1)

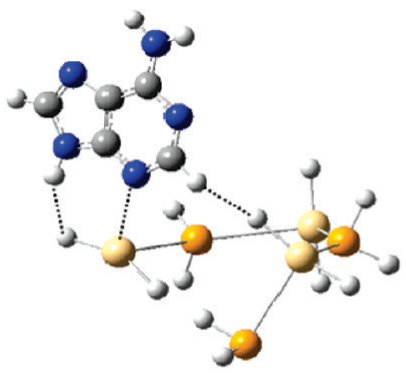

$\mathbf{E}=\mathbf{0}$

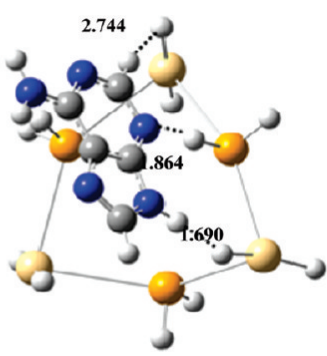

(3-H-a-2)

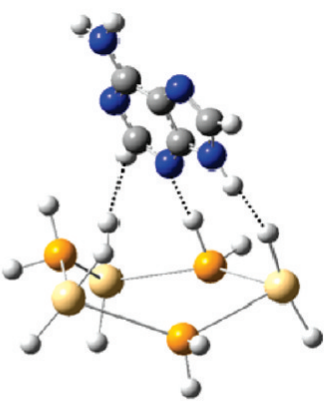

$E=\mathbf{3 . 0}$

Figure 5. Structures of $\mathrm{Cd}_{3} \mathrm{Se}_{3} \mathrm{H}_{12}-$ Ade complexes (relative energy in $\mathrm{kcal} / \mathrm{mol}$ ).

III-2. Structures of Hydrogen-Passivated Clusters: $\mathrm{Cd}_{n} \mathrm{Se}_{n} \mathrm{H}_{2 n}$-Ade and $\mathrm{Cd}_{n} \mathrm{Se}_{n} \mathrm{H}_{2 n-2}-$ Ade $(n=3,6,10,13)$. We use hydrogen atoms to simulate ligands as surface coordinating solvent molecules and stabilizing agents for computational convenience, although more realistic ligands may be needed to examine, for example, their steric effects on the structural and optical properties of ligand-passivated nonocrystal system. The passivated CdSe clusters also form the most stable complexes with $9(\mathrm{H})$-adenine. We find that the CdSe plane is significantly puckered in the $\mathrm{Cd}_{3} \mathrm{Se}_{3} \mathrm{H}_{12}$-Ade complex presented in Figure 5, as a result of interactions with adenine. N3 binds to $\mathrm{Cd}$ and $2(\mathrm{H})$ interacts with the $\mathrm{H}$ atom on $\mathrm{Se}$ in $(3-\mathrm{H}-\mathrm{a}-1)$. In (3-H-a-2), on the other hand, the adenine moiety positions above the $\mathrm{Cd}_{3} \mathrm{Se}_{3} \mathrm{H}_{12}$ cluster, interacting only with the ligands (hydrogen atoms). Three low energy conformers of the
$\mathrm{Cd}_{6} \mathrm{Se}_{6} \mathrm{H}_{12}-$ Ade complex (Figure 6) lie within $1 \mathrm{kcal} / \mathrm{mol}$, with the $D_{3}$ symmetry of $\mathrm{Cd}_{6} \mathrm{Se}_{6} \mathrm{H}_{12}$ significantly broken. $\mathrm{N} 3$ and $\mathrm{N} 7$ bind to $\mathrm{Cd}$ in the two lowest energy conformers (6-H-a-1) and (6-H-a-2) of $\mathrm{Cd}_{6} \mathrm{Se}_{6} \mathrm{H}_{12}-$ Ade complex (Figure 6), respectively. We find that in (6-H-a-3) a hydrogen atom is transferred from $\mathrm{Se}$ to N3. The hydrogen transfer is also observed in $\mathrm{Cd}_{n} \mathrm{Se}_{n} \mathrm{H}_{2 n}$-Ade $(n=10,13)$ complexes. In (10-H-a-1) and (13-H-a-1) (Figures 7 and 8), a hydrogen atom is transferred to $\mathrm{N} 3$ and N1, respectively, and it seems that interactions in these complexes are mainly characterized by those between the ligands and hydrogen atoms in Ade. This hydrogen transfer would not, however, be a typical phenomenon for other more realistic ligands such as phosphates.

When some ligands are removed from the passivated $\mathrm{CdSe}$ cluster, there may form covalent bonds with adenine, and in 


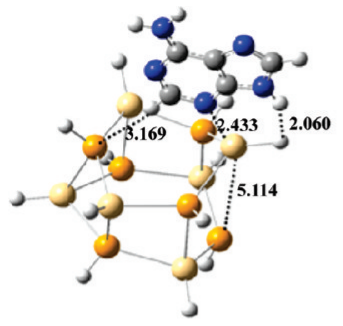

(6-H-a-1)

$$
\mathbf{E}=\mathbf{0}
$$

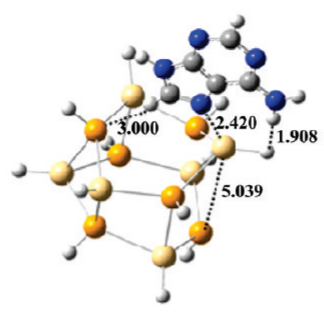

(6-H-a-2)

$\mathbf{E}=\mathbf{0 . 5}$

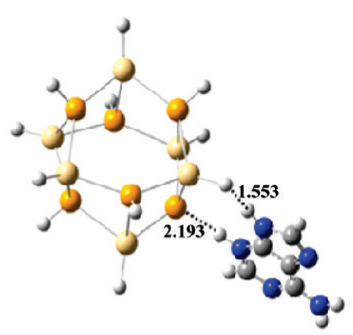

(6-H-a-3)
$\mathbf{E}=\mathbf{1 . 0}$

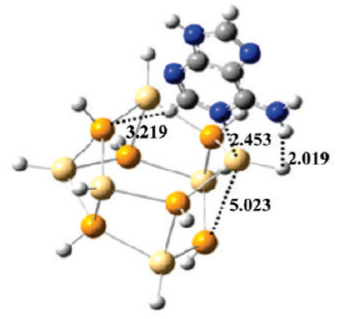

(6-H-a-4)

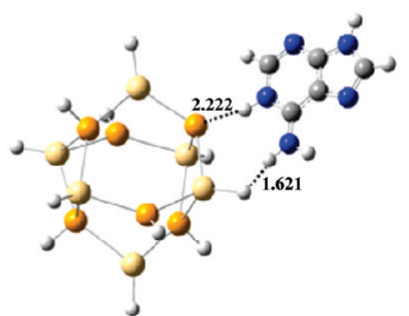

(6-H-a-5)

$\mathrm{E}=\mathbf{1 . 5}$

$E=2.6$

Figure 6. Structures of $\mathrm{Cd}_{6} \mathrm{Se}_{6} \mathrm{H}_{12}-$ Ade complexes (relative energy in kcal/mol).

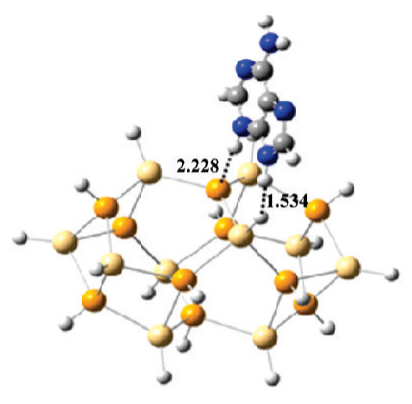

$(10-\mathrm{H}-\mathbf{a}-1)$

$$
\mathbf{E}=\mathbf{0}
$$

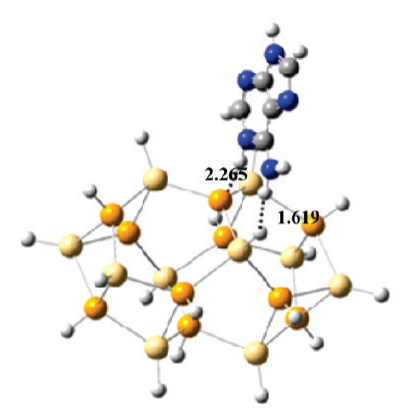

(10-H-a-2)

$\mathbf{E}=\mathbf{2 . 3}$

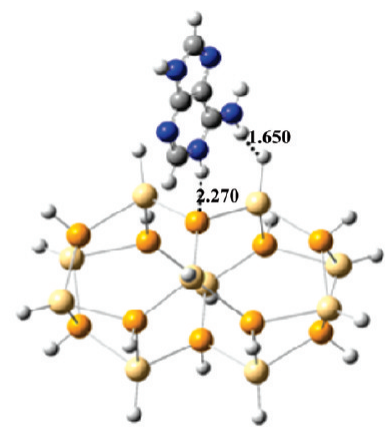

(10-H-a-3)

$\mathbf{E}=\mathbf{3 . 1}$

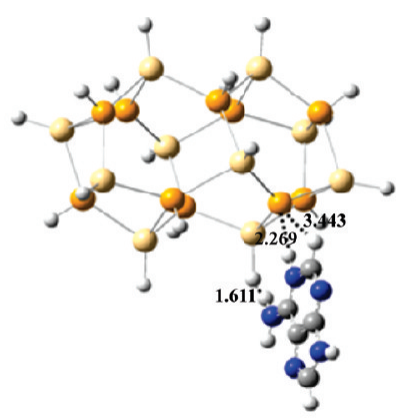

(10-H-a-4)

$E=3.2$

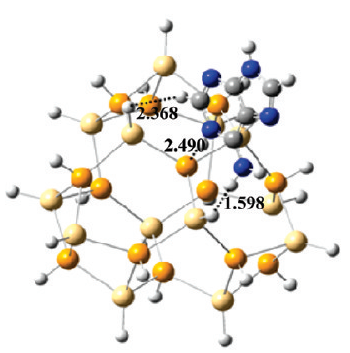

(13-H-a-1)

$\mathbf{E}=\mathbf{0}$

(13-H-a-2)

$E=1.0$

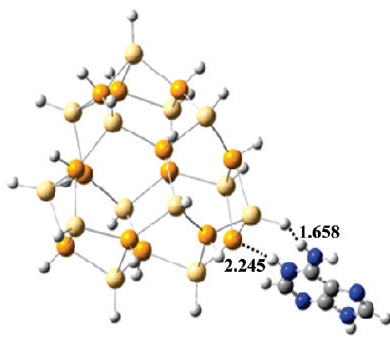

(13-H-a-5)

$E=3.4$

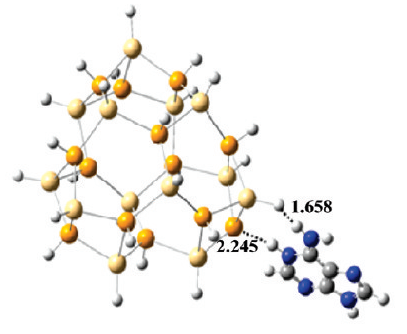

(13-H-a-3)

$E=1.7$

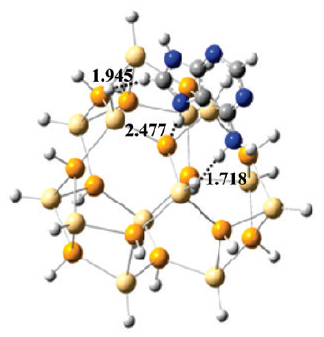

(13-H-a-6)

Figure 8. Structures of $\mathrm{Cd}_{13} \mathrm{Se}_{13} \mathrm{H}_{26}$-Ade complexes (relative energy in kcal/mol). 


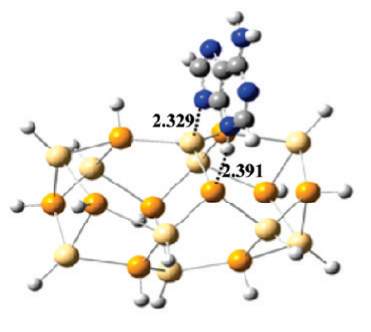

$\left(10-H_{18}-\mathbf{a}-1\right)$

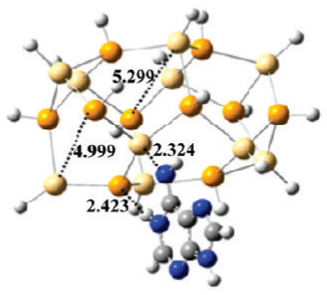

$\left(10-H_{18}-\mathbf{a}-2\right)$

$\mathbf{E}=\mathbf{2 . 9}$

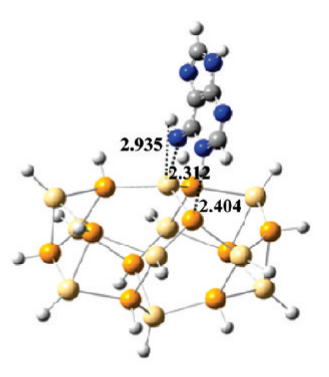

$\left(\mathbf{1 0}-\mathbf{H}_{18-\mathbf{a}-3)}\right.$

$E=4.4$

Figure 9. Structures of $\mathrm{Cd}_{10} \mathrm{Se}_{10} \mathrm{H}_{18}$-Ade complexes (relative energy in $\mathrm{kcal} / \mathrm{mol}$ ).

TABLE 1: Electronic Energy $E$ (Hartree), Zero Point Energy ZPE (kcal/mol), Vertical Excitation Energy VE (eV), and Oscillator Strength $f$ to the Four Lowest Excited States of Bare $\mathrm{Cd}_{n} \mathrm{Se}_{n}$ and $\mathrm{Cd}_{n} \mathrm{Se}_{n}-$ Adenine $\left._{(n}=3,6,10,13\right)$ Clusters

\begin{tabular}{|c|c|c|}
\hline & $E$ & $\mathrm{ZPE}$ \\
\hline \multicolumn{3}{|l|}{$\mathrm{Cd}_{3} \mathrm{Se}_{3}{ }^{a}$} \\
\hline (3) & -172.06454 & 2.3 \\
\hline \multicolumn{3}{|l|}{$\mathrm{Cd}_{3} \mathrm{Se}_{3}-\mathrm{Ade}$} \\
\hline$(3-a-1)$ & -639.55504 & 73.1 \\
\hline$(3-a-2)$ & -639.55099 & 73.2 \\
\hline$(3-a-3)$ & -639.55087 & 73.3 \\
\hline \multicolumn{3}{|l|}{$\mathrm{Cd}_{6} \mathrm{Se}_{6}$} \\
\hline (6) & -344.22297 & 5.1 \\
\hline \multicolumn{3}{|l|}{$\mathrm{Cd}_{6} \mathrm{Se}_{6}-$ Ade } \\
\hline$(6-a-1)$ & -811.71351 & 76.0 \\
\hline$(6-a-2)$ & -811.70917 & 76.2 \\
\hline$(6-a-3)$ & -811.70932 & 76.2 \\
\hline$(6-a-4)$ & -811.70848 & 76.1 \\
\hline$(6-a-5)$ & -811.70802 & 76.2 \\
\hline \multicolumn{3}{|l|}{$\mathrm{Cd}_{10} \mathrm{Se}_{10}{ }^{a}$} \\
\hline (10) & -573.76292 & 8.8 \\
\hline \multicolumn{3}{|l|}{$\mathrm{Cd}_{10} \mathrm{Se}_{10}-$ Ade } \\
\hline$(10-a-1)$ & -1041.25004 & 79.9 \\
\hline$(10-a-2)$ & -1041.25006 & 79.9 \\
\hline$(10-a-3)$ & -1041.24909 & 79.7 \\
\hline$(10-a-4)$ & -1041.24574 & 79.9 \\
\hline$(10-a-5)$ & -1041.24427 & 79.8 \\
\hline$(10-a-6)$ & -1041.24347 & 79.9 \\
\hline \multicolumn{3}{|l|}{$\mathrm{Cd}_{13} \mathrm{Se}_{13}{ }^{a}$} \\
\hline (13) & -745.92284 & 11.6 \\
\hline \multicolumn{3}{|l|}{$\mathrm{Cd}_{13} \mathrm{Se}_{13}-\mathrm{Ade}$} \\
\hline$(13-a-1)$ & -1213.40849 & 82.5 \\
\hline$(13-a-2)-1213.41091$ & 82.4 & $2.58,2.60,2.65,2.76$ \\
\hline$(13-\mathrm{a}-3)-1213.41091$ & 82.5 & $2.54,2.62,2.74,2.79$ \\
\hline$(13-a-4)$ & -1213.40918 & 82.6 \\
\hline$(13-a-5)$ & -1213.40918 & 82.6 \\
\hline$(13-a-6)$ & -1213.40849 & 82.5 \\
\hline$(13-a-7)$ & -1213.40752 & 82.6 \\
\hline$(13-a-8)$ & -1213.40730 & 82.6 \\
\hline$(13-a-9)$ & -1213.40803 & 83.1 \\
\hline
\end{tabular}

${ }^{a}$ Also reported in ref 9 .

Figures 9 and 10 we explore this possibility. When $9(\mathrm{H})$ and a $\mathrm{H}$ atom are removed from adenine and from $\mathrm{Cd}$ in the $\mathrm{Cd}_{10} \mathrm{Se}_{10} \mathrm{H}_{2 n}$-Ade complex, respectively, to form a covalent bond between N9 and Cd, a H-transfer is observed to occur from Se to $\mathrm{N} 3$, with the resulting structure $\left(10-\mathrm{H}_{18}-\mathrm{a}-1\right)$. Likewise, a N10-Cd covalent bond is formed with H-transfer accompanied from Se to $\mathrm{N} 1$ in $\left(13-\mathrm{H}_{24}-\mathrm{a}-1\right)$.

III-3. Ade-Binding Blue-Shifts the Electronic Excitations of Bare Nanoclusters $\mathbf{C d}_{n} \mathbf{S e}_{n}$. Table 1 presents the electronic transition energies to the four lowest excited states of $\mathrm{Cd}_{n} \mathrm{Se}_{n}$ and $\mathrm{Cd}_{n} \mathrm{Se}_{n}$-Ade complexes along with the oscillator strengths. They are calculated to be $2.4-3.3 \mathrm{eV}$. The transition energies to the first excited states of $\mathrm{Cd}_{n} \mathrm{Se}_{n}$ increase smoothly with
$2.44,2.44,2.87,3.30$

$2.60,2.74,3.10,3.36$

$2.62,2.72,3.07,3.37$

$2.62,2.73,3.09,3.37$

$2.48,2.48,2.63,2.94$

$2.58,2.62,2.76,2.97$

$2.58,2.63,2.75,2.98$

$2.58,2.62,2.75,2.96$

$2.61,2.61,2.73,2.92$

$2.59,2.62,2.75,2.94$

$2.51,2.64,2.72,2.72$

$2.54,2.68,2.76,2.78$

$2.54,2.67,2.75,2.78$

$2.53,2.68,2.72,2.78$

$2.54,2.68,2.73,2.78$

$2.56,2.69,2.76,2.80$

$2.55,2.68,2.72,2.77$

$2.57,2.57,2.71,2.80$

$2.60,2.61,2.74,2.79$

$0.0067,0.0038,0.0211,0.0332$

$0.0077,0.0049,0.0398,0.0169$

$2.54,2.61,2.73,2.78$

$2.53,2.61,2.73,2.77$

$2.60,2.61,2.74,2.78$

$2.56,2.62,2.74,2.79$

$2.60,2.62,2.72,2.76$

$2.62,2.66,2.73,2.81$
$0.0000,0.0000,0.0392,0.0000$

$0.0002,0.0028,0.0428,0.0018$ $0.0001,0.0013,0.0426,0.0008$ $0.0001,0.0014,0.0435,0.0014$

$0.0000,0.0000,0.0552,0.0000$

$0.0014,0.0054,0.0543,0.0063$ $0.0005,0.0011,0.0602,0.0036$ $0.0014,0.0027,0.0581,0.0054$ $0.0001,0.0003,0.0576,0.0059$ $0.0016,0.0036,0.0545,0.0055$

$0.0000,0.0340,0.0496,0.0000$

$0.0013,0.0308,0.0407,0.0177$ $0.0013,0.0319,0.0398,0.0179$ $0.0027,0.0305,0.0250,0.0210$ $0.0021,0.0321,0.0204,0.0249$ $0.0003,0.0403,0.0232,0.0225$ $0.0013,0.0326,0.0175,0.0266$

0.0044, 0.0044, 0.0524, 0.0000

$0.0019,0.0052,0.0539,0.0168$

$0.0051,0.0056,0.0505,0.0112$ $0.0050,0.0059,0.0484,0.0153$ $0.0026,0.0055,0.0540,0.0171$ $0.0072,0.0044,0.0464,0.0115$ 0.0077, 0.0036, 0.0257, 0.0300 $0.0061,0.0043,0.0234,0.0391$ cluster size $(2.44,2.48,2.51$, and $2.57 \mathrm{eV}$ for $n=3,6,10,13)$. This correlates well with the increasing number of valences in the $\mathrm{Cd}$ and Se atoms (from 2 in $\mathrm{Cd}_{3} \mathrm{Se}_{3}$ to 3 in $\mathrm{Cd}_{6} \mathrm{Se}_{6}$, and to 3 or 4 in $\mathrm{Cd}_{10} \mathrm{Se}_{10}$ and $\left.\mathrm{Cd}_{13} \mathrm{Se}_{13}\right)$. The vertical transition energies of the Ade-bound $\mathrm{Cd}_{n} \mathrm{Se}_{n}$ complexes are slightly blue-shifted by up to $0.18 \mathrm{eV}$ from those of the bare CdSe clusters (see also Figure 11). For example, the lowest vertical transition energies increases from 2.44, 2.48, 2.51, and $2.57 \mathrm{eV}$ for the bare $\mathrm{Cd}_{n} \mathrm{Se}_{n}$ clusters complexes to $\sim 2.60,2.60,2.55$, and $2.60 \mathrm{eV}$ for $\mathrm{Cd}_{n} \mathrm{Se}_{n}-$ Ade $(n=3,6,10,13)$ complexes, with significant increases in oscillator strengths. Changes in transition energies to the third lowest excited states may be best examined because they have the largest oscillator strengths. Despite their somewhat 


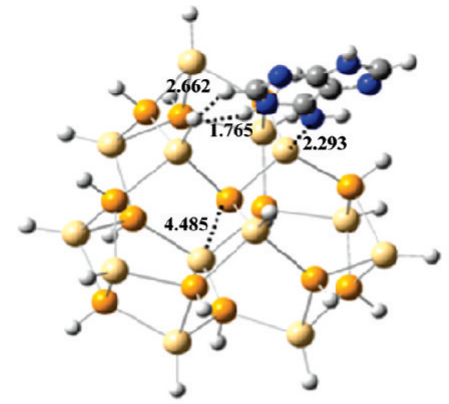

$\left(13-\mathrm{H}_{24}-\mathrm{a}-1\right)$

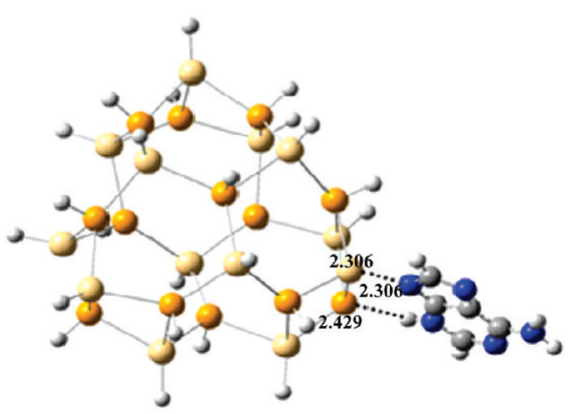

(13- $\left.\mathbf{H}_{24}-\mathbf{a}-3\right)$

$\mathrm{E}=\mathbf{3 . 5}$

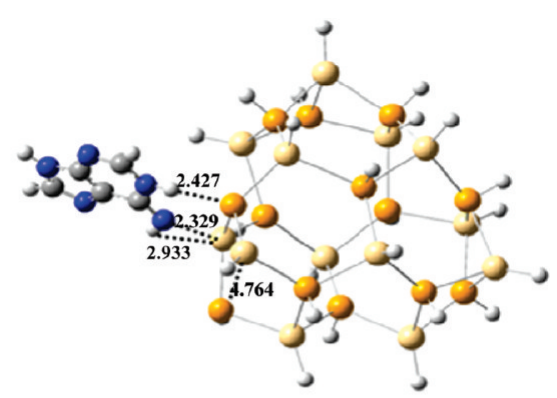

$\left(13-\mathrm{H}_{24}-\mathrm{a}-2\right) \quad \mathrm{E}=3.5$

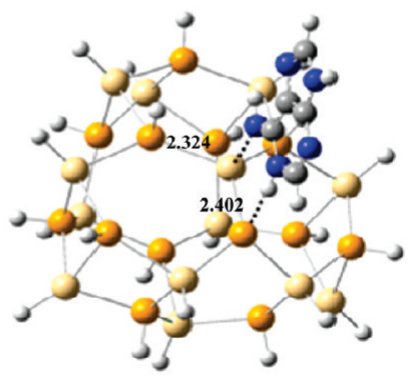

$\left(13-\mathrm{H}_{24}-\mathbf{a}-4\right)$

Figure 10. Structures of $\mathrm{Cd}_{13} \mathrm{Se}_{13} \mathrm{H}_{24}$-Ade complexes (relative energy in kcal/mol).

a)

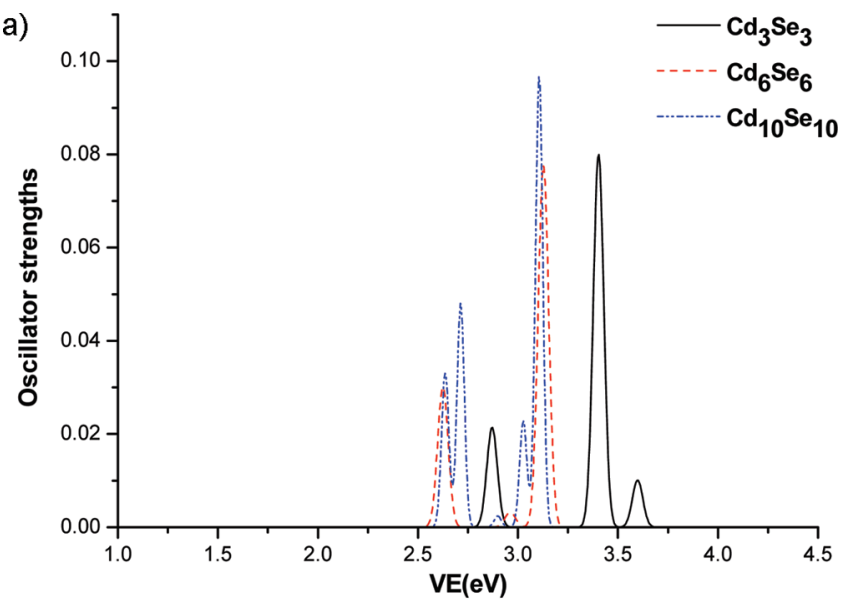

b)

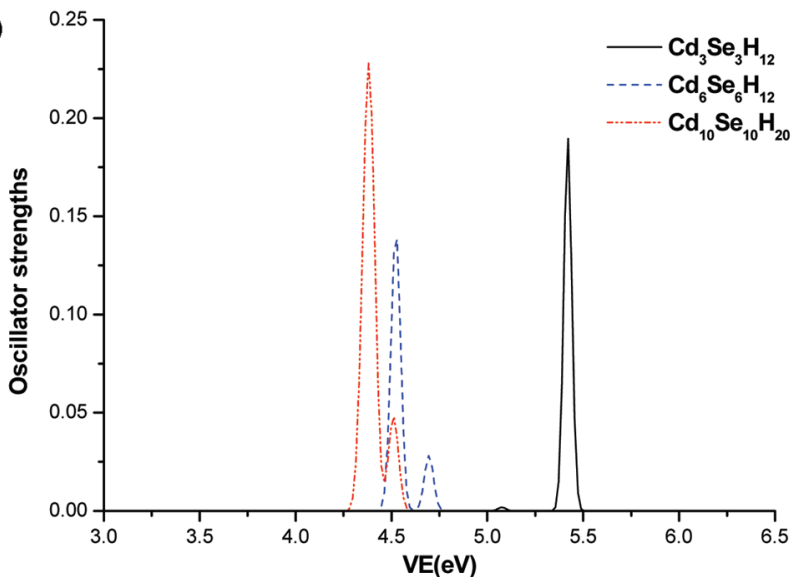

Figure 11. Electronic absorption spectra of the lowest energy structures of (a) $\mathrm{Cd}_{n} \mathrm{Se}_{n}(n=3,6,10)$ and (b) $\mathrm{Cd}_{3} \mathrm{Se}_{3} \mathrm{H}_{12}, \mathrm{Cd}_{6} \mathrm{Se}_{6} \mathrm{H}_{12}$, $\mathrm{Cd}_{10} \mathrm{Se}_{10} \mathrm{H}_{20}$.
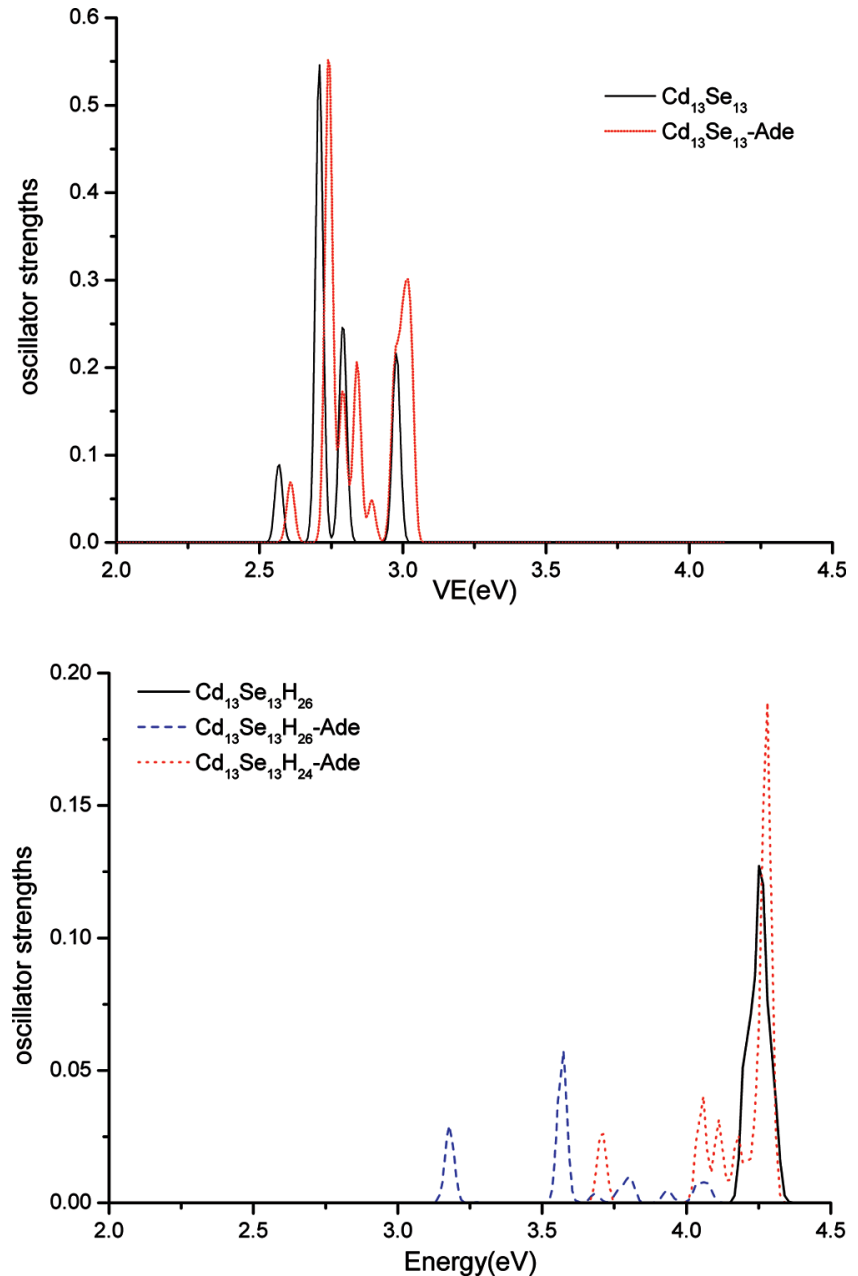

Figure 12. Electronic absorption spectra of the lowest energy structures of $\mathrm{Cd}_{13} \mathrm{Se}_{13}, \mathrm{Cd}_{13} \mathrm{Se}_{13}-\mathrm{Ade}, \mathrm{Cd}_{13} \mathrm{Se}_{13} \mathrm{H}_{26}, \mathrm{Cd}_{13} \mathrm{Se}_{13} \mathrm{H}_{26}-\mathrm{Ade}$, and $\mathrm{Cd}_{13} \mathrm{Se}_{13} \mathrm{H}_{24}-$ Ade complexes. 
TABLE 2: Electronic Energy $E$ (Hartree), Zero Point Energy ZPE (kcal/mol), Vertical Excitation Energy VE (eV), and Oscillator Strength $f$ to the Four Lowest Excited States of Passivated $\mathrm{Cd}_{3} \mathrm{Se}_{3} \mathrm{H}_{12}-$ and $\mathrm{Cd}_{n} \mathrm{Se}_{n} \mathrm{H}_{2 n}-\mathrm{Adenine}_{(\mathrm{N} 9)}(n=6,10,13)$ Clusters

\begin{tabular}{|c|c|c|c|c|}
\hline & $E$ & ZPE & VE & $f$ \\
\hline \multicolumn{5}{|l|}{$\mathrm{Cd}_{3} \mathrm{Se}_{3} \mathrm{H}_{12}{ }^{a}$} \\
\hline $\mathrm{Cd}_{3} \mathrm{Se}_{3} \mathrm{H}_{12}-$ Ade & & & & \\
\hline$(3-\mathrm{H}-\mathrm{a}-2)$ & -646.41495 & 119.3 & $4.92,4.93,4.96,4.97$ & $0.0324,0.0198,0.0257,0.0042$ \\
\hline \multicolumn{5}{|l|}{$\mathrm{Cd}_{6} \mathrm{Se}_{6} \mathrm{H}_{12}{ }^{a}$} \\
\hline \multicolumn{5}{|l|}{$\mathrm{Cd}_{6} \mathrm{Se}_{6} \mathrm{H}_{12}-$ Ade } \\
\hline$(6-\mathrm{H}-\mathrm{a}-2)$ & -818.62782 & 121.7 & $4.26,4.43,4.46,4.54$ & $0.1153,0.0095,0.0720,0.0005$ \\
\hline$(6-\mathrm{H}-\mathrm{a}-3)$ & -818.63025 & 123.8 & $2.91,3.13,3.17,3.34$ & $0.0059,0.0023,0.0873,0.0771$ \\
\hline$(6-\mathrm{H}-\mathrm{a}-4)$ & -818.62606 & 121.5 & $4.25,4.46,4.48,4.53$ & $0.1216,0.0674,0.0163,0.0533$ \\
\hline$(6-\mathrm{H}-\mathrm{a}-5)$ & -818.62854 & 124.2 & $3.14,3.24,3.25,3.33$ & $0.0001,0.0000,0.0038,0.0000$ \\
\hline \multicolumn{5}{|l|}{$\mathrm{Cd}_{10} \mathrm{Se}_{10} \mathrm{H}_{20}{ }^{a}$} \\
\hline$(10-\mathrm{H})$ & -585.57057 & 84.3 & $4.26,4.35,4.36,4.36$ & $0.0000,0.0000,0.1262,0.0000$ \\
\hline \multicolumn{5}{|l|}{$\mathrm{Cd}_{10} \mathrm{Se}_{10} \mathrm{H}_{18}-$ Ade } \\
\hline$\left(10-\mathrm{H}_{18}-\mathrm{a}-1\right)$ & -1051.59968 & 147.8 & $3.77,3.80,4.05,4.09$ & $0.0000,0.0856,0.0668,0.0021$ \\
\hline$\left(10-\mathrm{H}_{18}-\mathrm{a}-2\right)$ & -1051.59607 & 148.4 & $3.96,4.19,4.20,4.26$ & $0.0995,0.1692,0.0608,0.0002$ \\
\hline$\left(10-\mathrm{H}_{18}-\mathrm{a}-3\right)$ & -1051.59344 & 148.8 & $3.77,4.05,4.08,4.14$ & $0.0835,0.0685,0.0000,0.0685$ \\
\hline \multicolumn{5}{|l|}{$\mathrm{Cd}_{13} \mathrm{Se}_{13} \mathrm{H}_{26}{ }^{a}$} \\
\hline$(13-\mathrm{H})$ & -760.85118 & 110.2 & $4.23,4.24,4.24,4.27$ & $0.0000,0.0486,0.0504,0.1129$ \\
\hline \multicolumn{5}{|l|}{$\mathrm{Cd}_{13} \mathrm{Se}_{13} \mathrm{H}_{26}-$ Ade } \\
\hline$(13-\mathrm{H}-\mathrm{a}-1)$ & -1228.33385 & 184.7 & $3.16,3.26,3.56,3.67$ & $0.0263,0.0002,0.0541,0.0030$ \\
\hline$(13-\mathrm{H}-\mathrm{a}-2)$ & -1228.33129 & 184.1 & $3.24,3.34,3.58,3.59$ & $0.0001,0.0001,0.0002,0.0001$ \\
\hline$(13-\mathrm{H}-\mathrm{a}-3)-1228.33067$ & 183.8 & $3.01,3.14,3.22,3.56$ & $0.0000,0.0041,0.0000,0.0000$ & \\
\hline$(13-\mathrm{H}-\mathrm{a}-4)-1228.32974$ & 184.2 & $3.28,3.35,3.49,3.54$ & $0.0001,0.0000,0.0012,0.0014$ & \\
\hline$(13-\mathrm{H}-\mathrm{a}-5)$ & -1228.32773 & 184.2 & $3.18,3.29,3.34,3.40$ & $0.0000,0.0000,0.0020,0.0000$ \\
\hline \multicolumn{5}{|l|}{$\mathrm{Cd}_{13} \mathrm{Se}_{13} \mathrm{H}_{24}-\mathrm{Ade}$} \\
\hline
\end{tabular}

${ }^{a}$ Also reported in ref 9 .

irregular pattern as a function of $n(2.87,2.63,2.72,2.71 \mathrm{eV})$, the transition energies increase to $\sim 3.10,2.75,2.72$, and 2.74 $\mathrm{eV}$ as the result of conjugation with Ade. The blue shift becomes smaller with the increasing size of the CdSe cluster. Although the magnitudes of the calculated shifts for the $\mathrm{CdSe}-\mathrm{Ade}$ complexes seem to be small, larger biomolecules such as DNA including many bases are expected to give stronger blue shifts of the electronic spectra. Thus, our predictions for the prototypical model system will help to assign the experimental electronic spectra of the $\mathrm{CdSe}-\mathrm{Ade}$ complexes. Electronic absorption spectra of the lowest energy structures of $\mathrm{Cd}_{13} \mathrm{Se}_{13}$ and $\mathrm{Cd}_{13} \mathrm{Se}_{13}$-Ade are presented in Figure 12, which clearly demonstrates the blue shifts of the absorption bands.

III-4. Ade-Binding Red-Shifts the Electronic Excitations of Hydrogen-Passivated Clusters $\mathrm{Cd}_{n} \mathrm{Se}_{n} \mathrm{H}_{2 n}$. Conjugation of Ade to the H-passivated nanoclusters appears to red-shift transition energies, although there exist notable irregularities. Table 2 shows that vertical transition energy to the four lowest excited states of $\mathrm{Cd}_{3} \mathrm{Se}_{3} \mathrm{H}_{12}$-Ade complexes increases from $(4.55,4.65,4.82,4.91)$ to $(4.62,4.81,4.87,4.88) \mathrm{eV}$. For $n \geq$ 6 , however, the trend reverses, with vertical transition energies red-shifting as much as $1.2 \mathrm{eV}$. For example, vertical transition energies to the third lowest excited states of $\mathrm{Cd}_{n} \mathrm{Se}_{n} \mathrm{H}_{2 n}(n=$ $10,13)$ red-shift from $(4.36,4.24)$ to $(\sim 3.4,3.5) \mathrm{eV}$ as a result of conjugation with Ade. When a $\mathrm{Cd}-\mathrm{N}$ covalent is formed between adenine and the CdSe cluster, the magnitude of the red shift becomes much smaller $(0.1-0.5 \mathrm{eV})$ as given in Table 2 for $\mathrm{Cd}_{10} \mathrm{Se}_{10} \mathrm{H}_{18}-$ Ade and $\mathrm{Cd}_{13} \mathrm{Se}_{13} \mathrm{H}_{24}$-Ade complexes. This large difference between the electronic absorption spectra of $\mathrm{Cd}_{n} \mathrm{Se}_{n} \mathrm{H}_{2 n}$-Ade and $\mathrm{Cd}_{n} \mathrm{Se}_{n} \mathrm{H}_{2 \mathrm{n}-2}-$ Ade $(n=10,13)$ will help to elucidate the nature of interactions between $\mathrm{CdSe}$ and adenine from the experimentally observed electronic spectra of the complexes. Electronic absorption spectra of the lowest energy structures of $\mathrm{Cd}_{13} \mathrm{Se}_{13} \mathrm{H}_{26}, \mathrm{Cd}_{13} \mathrm{Se}_{13} \mathrm{H}_{26}-\mathrm{Ade}$, and $\mathrm{Cd}_{13} \mathrm{Se}_{13} \mathrm{H}_{24}$-Ade complexes are presented in Figure 12. The absorption bands of $\mathrm{Cd}_{13} \mathrm{Se}_{13} \mathrm{H}_{26}$ are concentrated at $\sim 4.3 \mathrm{eV}$, whereas those for $\mathrm{Cd}_{13} \mathrm{Se}_{13} \mathrm{H}_{26}$ - Ade and $\mathrm{Cd}_{13} \mathrm{Se}_{13} \mathrm{H}_{24}-$ Ade are significantly red-shifted to $3.2-4.1$ and $3.7-4.3 \mathrm{eV}$, respectively.

III-5. NBO Analysis of the Electronic Transitions in $\mathrm{Cd}_{13} \mathrm{Se}_{13}$-Ade and $\mathrm{Cd}_{13} \mathrm{Se}_{13} \mathbf{H}_{26}$-Ade. Table 3 presents the natural bond orbital (NBO) components of the HOMO and LUMO of the lowest energy structures of (a) $\mathrm{Cd}_{n} \mathrm{Se}_{n}$ ( $n=3,6$, 10) and (b) $\mathrm{Cd}_{3} \mathrm{Se}_{3} \mathrm{H}_{12}, \mathrm{Cd}_{6} \mathrm{Se}_{6} \mathrm{H}_{12}$, and $\mathrm{Cd}_{10} \mathrm{Se}_{10} \mathrm{H}_{20}$. For the unpassivated $\mathrm{Cd}_{n} \mathrm{Se}_{n}(n=3,6,10)$, the HOMO is essentially of Se lone pair characters, whereas there are some contributions of CdSe antibonds and $\mathrm{Cd} \mathrm{5p,6p} \mathrm{in} \mathrm{LUMO.} \mathrm{For} \mathrm{the} \mathrm{H}$ passivated clusters $\mathrm{Cd}_{6} \mathrm{Se}_{6} \mathrm{H}_{12}$ and $\mathrm{Cd}_{10} \mathrm{Se}_{10} \mathrm{H}_{20}$, contributions from $\mathrm{Cd}-\mathrm{H}$ bonds and $\mathrm{Se} 4 \mathrm{p}, 4 \mathrm{~s}$ are noticeable in the HOMO, 
TABLE 3: Contributions of Different Natural Bond Orbitals to the HOMO and LUMO of the Lowest Energy Structures of (a) $\mathrm{Cd}_{n} \mathrm{Se}_{n}(n=3,6,10)$ and (b) $\mathrm{Cd}_{3} \mathrm{Se}_{3} \mathrm{H}_{12}$, $\mathrm{Cd}_{6} \mathrm{Se}_{6} \mathrm{H}_{12}$, and $\mathrm{Cd}_{10} \mathrm{Se}_{10} \mathrm{H}_{20}$

\begin{tabular}{|c|c|c|c|c|c|c|}
\hline \multicolumn{7}{|c|}{ (a) $\mathrm{Cd}_{3} \mathrm{Se}_{3}, \mathrm{Cd}_{6} \mathrm{Se}_{6}, \mathrm{Cd}_{10} \mathrm{Se}_{10}$} \\
\hline & \multicolumn{2}{|c|}{$\mathrm{Cd}_{3} \mathrm{Se}_{3}$} & \multicolumn{2}{|c|}{$\mathrm{Cd}_{6} \mathrm{Se}_{6}$} & \multicolumn{2}{|c|}{$\mathrm{Cd}_{10} \mathrm{Se}_{10}$} \\
\hline & HOMO & LUMO & HOMO & LUMO & HOMO & LUMO \\
\hline $\begin{array}{l}\text { CdSe } \\
\text { bonds }\end{array}$ & & & 0.10 & & 0.07 & \\
\hline $\begin{array}{l}\text { CdSe } \\
\text { antibonds }\end{array}$ & & 0.58 & 0.02 & 0.52 & 0.03 & 0.59 \\
\hline $\begin{array}{l}\text { Se } 4 s, 4 p \\
\text { lone pairs }\end{array}$ & 0.99 & 0.16 & 0.86 & 0.15 & 0.88 & 0.17 \\
\hline Cd $5 p, 6 p$ & & 0.24 & & 0.33 & 0.01 & 0.22 \\
\hline \multicolumn{7}{|c|}{ (b) $\mathrm{Cd}_{3} \mathrm{Se}_{3} \mathrm{H}_{12}, \mathrm{Cd}_{6} \mathrm{Se}_{6} \mathrm{H}_{12}, \mathrm{Cd}_{10} \mathrm{Se}_{10} \mathrm{H}_{20}$} \\
\hline & \multicolumn{2}{|c|}{$\mathrm{Cd}_{3} \mathrm{Se}_{3} \mathrm{H}_{12}$} & \multicolumn{2}{|c|}{$\mathrm{Cd}_{6} \mathrm{Se}_{6} \mathrm{H}_{12}$} & \multicolumn{2}{|c|}{$\mathrm{Cd}_{10} \mathrm{Se}_{10} \mathrm{H}_{20}$} \\
\hline & HOMO & LUMO & HOMO & LUMO & HOMO & LUMO \\
\hline $\begin{array}{l}\mathrm{Cd}-\mathrm{H} \\
\text { bonds }\end{array}$ & 0.37 & & 0.11 & & 0.60 & \\
\hline $\begin{array}{l}\mathrm{Cd}-\mathrm{H} \\
\text { antibonds }\end{array}$ & 0.12 & 0.01 & & 0.59 & 0.03 & 0.68 \\
\hline $\mathrm{H} 1 \mathrm{~s}, 2 \mathrm{~s}, 3 \mathrm{~s}, 2 \mathrm{p}$ & 0.49 & 0.38 & & 0.04 & & 0.01 \\
\hline $\mathrm{Cd} 5 \mathrm{p}, 4 \mathrm{~d}, 6 \mathrm{~s}$ & 0.01 & 0.16 & & 0.05 & 0.02 & \\
\hline Se $4 p, 4 s$ & & & 0.86 & 0.10 & 0.32 & 0.09 \\
\hline $\mathrm{Se}-\mathrm{H}^{*}$ & & 0.36 & & 0.18 & & 0.10 \\
\hline Se $5 p$ & & 0.04 & & 0.10 & & \\
\hline
\end{tabular}

TABLE 4: Contributions of Different Natural Bond Orbitals to the HOMO and LUMO of $\mathrm{Cd}_{13} \mathrm{Se}_{13}-$ Ade and $\mathrm{Cd}_{13} \mathrm{Se}_{13} \mathrm{H}_{26}-$ Ade $^{a}$

\begin{tabular}{lccccc}
\hline & \multicolumn{2}{c}{$\mathrm{Cd}_{13} \mathrm{Se}_{13}-\mathrm{Ade}$} & & $\mathrm{Cd}_{13} \mathrm{Se}_{13} \mathrm{H}_{26}-\mathrm{Ade}$ \\
\cline { 2 - 3 } & $\mathrm{HOMO}$ & LUMO & & $\mathrm{HOMO}$ & LUMO \\
\hline CdSe bonds & 0.15 & 0.00 & & \\
CdSe antibonds & 0.02 & 0.62 & & \\
Se 4s, 4p lone pairs & 0.64 & 0.21 & & 0.70 & 0.00 \\
Cd 5p & 0.00 & 0.12 & & \\
Ade bonds, lone pairs & 0.00 & 0.00 & & 0.01 & 0.05 \\
Ade C-N* & 0.00 & 0.00 & & 0.00 & 0.81
\end{tabular}

${ }^{a}$ Note: The CdSe antibonding orbitals of $\mathrm{Cd}_{13} \mathrm{Se}_{13}-$ Ade are about $90 \%$ made of $\mathrm{Cd} 5$ s orbitals. The $\mathrm{Cd}-\mathrm{Se}$ bonds and $\mathrm{Cd}-\mathrm{Se}$ antibonding orbitals of $\mathrm{Cd}_{13} \mathrm{Se}_{13}$-Ade appear to be replaced by $\mathrm{Cd}-\mathrm{H}$ bonds and $\mathrm{Se}-\mathrm{H}$ bonds in $\mathrm{Cd}_{13} \mathrm{Se}_{13} \mathrm{H}_{26}-\mathrm{Ade}$. The $\mathrm{Cd}-\mathrm{H}$ and $\mathrm{Se}-\mathrm{H}$ bonds are not listed because they contribute little to the frontier orbitals of $\mathrm{Cd}_{13} \mathrm{Se}_{13} \mathrm{H}_{26}-$ Ade. The $\mathrm{C}-\mathrm{N}^{*}$ antibonding orbitals that contribute to the LUMO of $\mathrm{Cd}_{13} \mathrm{Se}_{13} \mathrm{H}_{26}-$ Ade are mostly made of carbon and nitrogen $2 p$ orbitals. This is expected because the LUMO of $\mathrm{Cd}_{13} \mathrm{Se}_{13} \mathrm{H}_{26}-\mathrm{Ade}$ is a $\pi^{*}$ molecular orbital.

but the LUMO is largely of $\mathrm{Cd}-\mathrm{H}$ antibonds character. It seems that the behavior in $\mathrm{Cd}_{6} \mathrm{Se}_{6} \mathrm{H}_{12}$ is quite different ( $\mathrm{H}$ orbitals are significant both in the HOMO and in the LUMO), as expected from its different bonding character.

Table 4 presents similar analysis for lowest energy $\mathrm{Cd}_{13} \mathrm{Se}_{13}$-Ade and $\mathrm{Cd}_{13} \mathrm{Se}_{13} \mathrm{H}_{26}$-Ade. It seems that the HOMO (LUMO) of $\mathrm{Cd}_{13} \mathrm{Se}_{13}$-Ade complex is mostly Se 4s/p (Cd 5s/ p), much like the frontier orbitals of $\mathrm{Cd}_{13} \mathrm{Se}_{13}$. This similarity between the orbitals involved in the electronic transitions of $\mathrm{Cd}_{13} \mathrm{Se}_{13}$ and $\mathrm{Cd}_{13} \mathrm{Se}_{13}$-Ade seems to account for the small shift $(<0.05 \mathrm{eV})$ in excitation energy induced by Ade. On the other hand, although the $\mathrm{HOMO}$ of $\mathrm{Cd}_{13} \mathrm{Se}_{13} \mathrm{H}_{26}$-Ade is mostly Se $4 \mathrm{~s} / \mathrm{p}$, the LUMO has a lot of contribution from the $\mathrm{C}-\mathrm{N}$ antibonding orbitals. This dominant contribution of the ligand antibonding orbitals can be clearly seen in the LUMO isosurface depicted in Figure 13. The isosurface suggests that the LUMO is clearly a $\pi^{*}$ orbital of the purine ring. Thus, it appears that the large red shift in the excitation spectrum of (a) $\mathrm{Cd}_{13} \mathrm{Se}_{13}$ - Ade

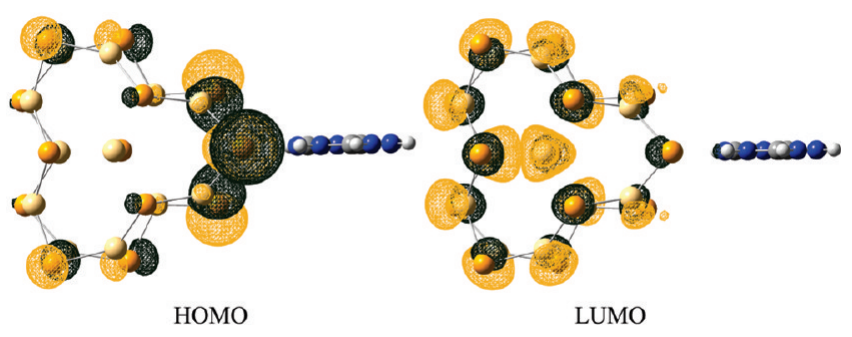

(b) $\mathrm{Cd}_{13} \mathrm{Se}_{13} \mathrm{H}_{26}$ - Ade

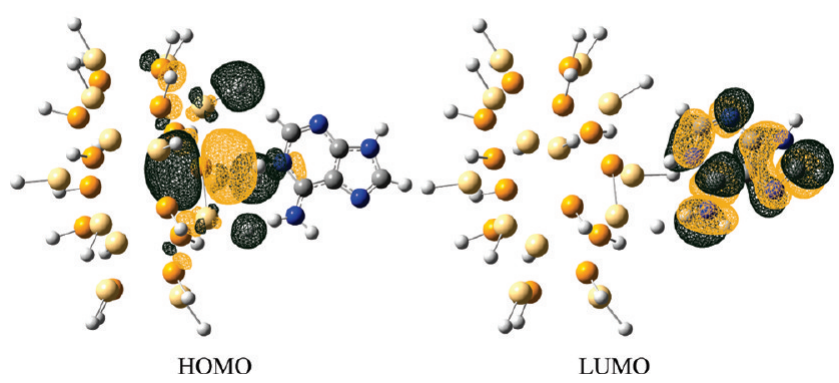

Figure 13. HOMO and LUMO of $\mathrm{Cd}_{13} \mathrm{Se}_{13}-\mathrm{Ade}$ and $\mathrm{Cd}_{13} \mathrm{Se}_{13} \mathrm{H}_{26}$.

$\mathrm{Cd}_{13} \mathrm{Se}_{13} \mathrm{H}_{26}$-Ade is related to the charge transfer from the $\mathrm{Cd}_{13} \mathrm{Se}_{13} \mathrm{H}_{26}$ to Ade. It may be useful to note that $\mathrm{Cd}_{13} \mathrm{Se}_{13}-\mathrm{Ade}$ and $\mathrm{Cd}_{13} \mathrm{Se}_{13} \mathrm{H}_{26}$-Ade have different binding orientations: The $\mathrm{Cd}_{13} \mathrm{Se}_{13}$-Ade has Ade attached from the side, whereas has Ade binds from the top in $\mathrm{Cd}_{13} \mathrm{Se}_{13} \mathrm{H}_{26}$-Ade. It may be that this difference in bonding orientation leads to the LUMO of $\mathrm{Cd}_{13} \mathrm{Se}_{13} \mathrm{H}_{26}-$ Ade with so much Ade character.

In conclusion, we calculated structures and electronic spectra for $\mathrm{Cd}_{n} \mathrm{Se}_{n}-$ Ade and the $\mathrm{Cd}_{n} \mathrm{Se}_{n} \mathrm{H}_{2 n}$-Ade $(n \leq 13)$. Binding of Ade blue-shifts the electronic excitations of the bare CdSe but red-shifts those of hydrogen-passivated CdSe. A comparison of the natural bond orbitals involved in the electronic transitions shows that the large excitation energy red shift of $\mathrm{Cd}_{n} \mathrm{Se}_{n} \mathrm{H}_{2 n}$-Ade is caused by the purine $\Pi^{*}$ orbital acting as a particle trap. Experiments on this interesting system will be highly desirable.

Acknowledgment. This work was supported by the KOSEF 2009-0070597 (basic research program) and by the Petroleum Research Fund. B.K. acknowledges the financial support by the "Center for Nanostructured Materials Technology" (08K150102210) under 21st century Frontier R\&D programs of the MEST, Korea.

Supporting Information Available: Lists of energy, ZPE, and Gibbs function and coordinates. This material is available free of charge via the Internet at http://pubs.acs.org.

\section{References and Notes}

(1) Sarikaya, M.; Tamerler, C.; Jen, A.; Schulten, K.; Baneyx, F. Nature-Mater. 2004, 2, 577.

(2) Whaley, S.; English, D.; Hu, E.; Barbara, P.; Belcher, A. Nature 2000, 405, 665 .

(3) Flynn, C.; Lee, S.-W.; Peelle, B.; Belcher, A. Acta Mater. 2003, $51,5867$.

(4) Seeman, N.; Belcher, A. Proc. Natl. Acad. Sci. 2002, 99, 6451.

(5) Peelle, B.; Krauland, E.; Wittrup, K.; Belcher, A. Langmuir 2005, 21,6929

(6) Mattoussi, H.; Mauro, J. M.; Goldman, E. R.; Anderson, G. P.; Sundar, V. C.; Mikulec, F. V.; Bawendi, M. G. J. Am. Chem. Soc. 2000, $122,12142$. 1639 
(8) Gill, R.; Willner, I.; Shweky, I.; Banin, U. J. Phys. Chem. B 2005, 109, 23715.

(9) Chung, S.-Y.; Lee, S. C.; Liu, S.; Neuhauser, D. J. Phys. Chem. B 2009, 113, 292.

(10) Cohen, R.; Kronik, L.; Shanzer, A.; Cahen, D.; Liu, A.; Rosenwaks, Y.; Lorenz, J. K.; Ellis, A. B. J. Am. Chem. Soc. 1999, 121, 10545.

(11) Artemyev, M.; Kisiel, D.; Abmiotko, S.; Antipina, M. N.; Khomutov, G. B.; Kislov, V. V.; Rakhnyanskaya, A. A. J. Am. Chem. Soc. 2004, 126, 10594.

(12) Pinaud, F.; King, D.; Moore, H.-P.; Weiss, S. J. Am. Chem. Soc.

2004, 126, 6115 .

(13) Chen, F.; Gerion, D. Nano Lett. 2004, 4, 1827.

(14) Patolsky, F.; Gill, R.; Weizmann, Y.; Mokari, T.; Banin, U.; Willner, I. J. Am. Chem. Soc. 2003, 125, 13918. 7602 .

(15) Gill, R.; Zayats, M.; Willner, I. Angew. Chem., Int. Ed. 2008, 47,

(16) Ma, N.; Yang, J.; Stewart, K. M.; Kelley, S. O. Langmuir 2007, $23,12783$.

(17) Sandros, M. G.; Gao, D.; Benson, D. E. J. Am. Chem. Soc. 2005, 127, 12198.

(18) Clapp, A. R.; Medintz, I. L.; Fisher, B. R.; Anderson, G. P.; Mattoussi, H. J. Am. Chem. Soc. 2005, 127, 1242.

(19) Bakalova, R.; Ohba, H.; Zhelev, Z.; Nagase, T.; Jose, R.; Ishikawa, M.; Baba, Y. Nano Lett. 2004, 4, 1567.

(20) Schlamp, M. C.; Peng, X.; Alivisatos, A. P. J. Appl. Phys. 1997, 82,5837

(21) Klimov, V. I.; Mikhailovsky, A. A.; Xu, S.; Malko, A.; Hollingsworth, J. A.; Leatherdale, C. A.; Eisler, H.-J.; Bawendi, M. G. Science 2000, 290, 314.

(22) Liu, P.; Wang, Q.; Li, X. J. Phys. Chem. C 2009, 113, 7670.

(23) Freeman, R.; Finder, T.; Bahshi, L.; Willner, I. Nano Lett. 2009, $9,2037$. 3.

(24) Smith, A.; Ruan, G.; Rhyner, M.; Nie, S. Biomed. Eng. 2006, 34,

(25) Michalet, X.; Pinaud, F.; Bentolila, L.; Tsay, J.; Doose, S.; Li, J.; Sundaresan, G.; Wu, A.; Gambhir, S.; Weiss, S. Science 2005, 307, 538. (26) Eichkorn, K.; Ahlrichs, R. Chem. Phys. Lett. 1998, 288, 235.

(27) Deglmann, P.; Ahlrichs, R.; Tsereteli, K. J. Chem. Phys. 2002, 116, 1585 .

(28) Leung, K.; Whaley, K. B. J. Chem. Phys. 1999, 110, 11012.

(29) Troparevsky, M. C.; Chelikowsky, J. R. J. Chem. Phys. 2001, 114, 943.

(30) Troparevsky, M. C.; Kronik, L.; Chelikowsky, J. R. J. Chem. Phys. 2003, 119, 2284.

(31) Puzder, A.; Williamson, A. J.; Gygi, F.; Galli, G. Phys. Rev. Lett. 2004, 92, 217401.

(32) Peng, Z. A.; Peng, X. J. Am. Chem. Soc. 2001, 123, 1389.

(33) Nirmal, M.; Norris, D. J.; Kuno, M.; Bawendi, M. G.; Efros, A. L.; Rosen, M. Phys. Rev. Lett. 1995, 75, 3728.
(34) Efros, A. L.; Rosen, M.; Kuno, M.; Nirmal, M.; Norris, D. J.; Bawendi, M. G. Phys. Rev. B 1996, 54, 4843.

(35) Fisher, B. R.; Eisler, H. J.; Stott, N. E.; Bawendi, M. G. J. Phys. Chem. B 2004, 108, 143.

(36) Qu, L.; Peng, X. J. Am. Chem. Soc. 2002, 124, 2049.

(37) Ebenstein, Y.; Mokari, T.; Banin, U. Appl. Phys. Lett. 2002, 80, 4033.

(38) de Mello Donega, C.; Hickey, S. G.; Wuister, S. F.; Vanmaekelberg, D.; Meijerink, A. J. Phys. Chem. B 2003, 107, 489.

(39) Lim, S. J.; Chon, B.; Joo, T.; Shin, S. K. J. Phys. Chem. C 2008, $112,1744$.

(40) Joo, J.; Son, J. S.; Kwon, S. G.; Yu, J. H.; Hyeon, T. J. Am. Chem. Soc. 2006, 128,5632 .

(41) Jose, R.; Zhanpeisov, N. U.; Fukumura, H.; Baba, Y.; Ishikawa, M. J. Am. Chem. Soc. 2006, 128, 629.

(42) Jacobsohn, M.; Banin, U. J. Phys. Chem. B 1999, 104, 1.

(43) Li, L.-s.; Hu, J.; Yang, W.; Alivisatos, A. P. Nano Lett. 2001, 1, 349.

(44) Zlateva, G.; Zhelev, Z.; Bakalova, R.; Kanno, I. Inorg. Chem. 2007, 46,6212 .

(45) Manna, L.; Scher, E. C.; Alivisatos, A. P. J. Am. Chem. Soc. 2000, 122,12700 .

(46) Jasieniak, J.; Mulvaney, P. J. Am. Chem. Soc. 2007, 129, 2841.

(47) Behrens, S.; Bettenhausen, M.; Eichhöfer, A.; Fenske, D. Angew. Chem., Int. Ed. Engl. 1997, 36, 2797.

(48) Soloviev, V. N.; Eichhöfer, A.; Fenske, D.; Banin, U. J. Am. Chem. Soc. 2001, 123, 2354.

(49) Frisch, M. J.; Trucks, G. W.; Schlegel, H. B.; Scuseria, G. E.; Robb, M. A.; Cheeseman, J. R.; Montgomery, J. A., Jr.; Vreven, T.; Kudin, K. N.; Burant, J. C.; Millam, J. M.; Iyengar, S. S.; Tomasi, J.; Barone, V.; Mennucci, B.; Cossi, M.; Scalmani, G.; Rega, N.; Petersson, G. A.; Nakatsuji, H.; Hada, M.; Ehara, M.; Toyota, K.; Fukuda, R.; Hasegawa, J.; Ishida, M.; Nakajima, T.; Honda, Y.; Kitao, O.; Nakai, H.; Klene, M.; Li, X.; Knox, J. E.; Hratchian, H. P.; Cross, J. B.; Bakken, V.; Adamo, C.; Jaramillo, J.; Gomperts, R.; Stratmann, R. E.; Yazyev, O.; Austin, A. J.; Cammi, R.; Pomelli, C.; Ochterski, J. W.; Ayala, P. Y.; Morokuma, K.; Voth, G. A.; Salvador, P.; Dannenberg, J. J.; Zakrzewski, V. G.; Dapprich, S.; Daniels, A. D.; Strain, M. C.; Farkas, O.; Malick, D. K.; Rabuck, A. D.; Raghavachari, K.; Foresman, J. B.; Ortiz, J. V.; Cui, Q.; Baboul, A. G.; Clifford, S.; Cioslowski, J.; Stefanov, B. B.; Liu, G.; Liashenko, A.; Piskorz, P.; Komaromi, I.; Martin, R. L.; Fox, D. J.; Keith, T.; Al-Laham, M. A.; Peng, C. Y.; Nanayakkara, A.; Challacombe, M.; Gill, P. M. W.; Johnson, B.; Chen, W.; Wong, M. W.; Gonzalez, C.; Pople, J. A. Gaussian 03; Gaussian, Inc.: Wallingford, CT, 2004.

(50) Becke, A. D. J. Chem. Phys. 1993, 98, 5648.

(51) Lee, C.; Yang, W.; Parr, R. P. Phys. Rev. B 1988, 37, 785.

(52) Hanus, M.; Kabelá, M.; Rejnek, J.; Ryjáek, F.; Hobza, P. J. Phys. Chem. B 2004, 108, 2087.

JP907725F 